\title{
SHARED THEMES, DIFFERENT COUNTRIES: QUR'ANIC INTERPRETATION IN THE TWENTIETH CENTURY INDONESIA AND EGYPT
}

\author{
Norbani B Ismail \\ Visiting Professor, Syarif Hidayatullah State Islamic University (UIN) Jakarta \\ norbani.bt.ismail@gmail.com
}

\begin{abstract}
This paper studies the interpretations of the Qur'an in the twentieth century Indonesia and Egypt. It examines the interpretation of Hamka and of al-Sha'rawi on verses related to women's issues such as gender equality, polygamy, and modesty. The study analyses their use of various exegetical tools that enable them to use their interpretations on the issues to evoke and affirm spiritual consciousness, construct a Muslim identity, and to use them as a platform for social criticism. The study finds that despite their geographical distance, both tafsir works share similar embedded themes: creating awareness of one's religious identity, instilling spiritual-theological consciousness among the Muslims, and continuity of the legacy of exegetical tradition.
\end{abstract}

Keywords: Tafsir, women, Indonesia, Egypt

\section{Introduction}

The twentieth-century Islamic scholarship was inspired and molded by its myriads of socio-economic and political realities in the Muslim societies. Decolonized Muslim leaders and bureaucrats now dedicated more time and effort in building their nations where Muslim scholars and 'ulamā' articulate religious interpretations through various intellectual platforms to respond to the changing needs of the society. In the context of interpretation of the Qur'an (tafsìr), intriguing development took place where more works were written in various parts of the Muslim world, and in various vernacular languages, thus indicates the proliferation and the demand of religious writings. This paper studies the twentieth-century tafsir works of Indonesian Haji Abdul Malik Abdul Karim Amrullah [HAMKA] (d.1981) and Egyptian Muhammad Mutawallī al-Sha' rāwī (d. 1998). It aims at unpacking common themes that help to discern a better understanding of major shared themes in their works that could be counted as representatives of general features of the tafsir works in that century.

The paper studies Hamka's and al-Sha'rāwī's interpretations on verses related to women's issues such as gender equality, polygamy, and modesty. Their hermeneutical approaches in rendering these verses help to identify how the two scholars presented and appropriated the Qur'an in their respective socio-political contexts. The paper aims at identifying the common shared themes in these exegetical works that help to understand the general history of Qur'anic scholarship in the twentieth century. It also helps to point to a larger social context where the public showed greater interest towards Islam and the message of the Qur'an. The production of tafsir works during this time also points to the practice of democratization of Islamic scholarship and interpreting authority in the Muslim societies in which more scholars took part in producing works that speak to the heart and mind of the public. In this paper, there are two guiding questions I hope to answer: what are the common shared themes in the twentieth-century tafsir works? How do the exegetes construct socio- 
religious issues particularly on women's issues that confronted the Muslims during this time that fit within the spirit of Qur'anic framework? The paper has consulted several major works written by Hamka and al-Sha'rāwī' such as Tafsir Al-Azhar 1984a), Kedudukan Perempuan Dalam Islam (1984b), Soal Jawab Agama Islam (1984c), Tafsīr al-Sha'rāwì (n.d.), AlShaykh al-Sha 'rāwī wa al-Mar'ah al-Muslimah (n.d), Kayfa Nafham al-Islām (1982), and Al-Mar'ah fi al-Qur'an al-Karim (1990) in exploring their interpretations on verses related to gender equality, polygamy and modesty. It also referred the following works: The Formation of the Classical Tafsìr Tradition: The Qur'an Commentary of al-Tha'labi (Saleh, 2004), "Qur'anic Commentaries" (Saleh, 2015), Defining Islam for the Egyptian State: Muftis and Fatwas of Dār al-Iftà' (Skovgaard-Petersen, 1997), The Ulama in Contemporary Islam: Custodians of Change (Zaman, 2002), and A Quiet Revolution: The Veil's Resurgence, from the Middle East to America (Ahmed, 2011) in identifying and analyzing the shared themes of the exegetical works in Indonesia and Egypt in the twentieth century.

\section{The Making of Qur'anic Exegetes: Hamka and al-Sha'rāwī}

Hamka or Haji Abdul Malik Abdul Karim Amrullah's (1908-1983) journey to scholarship was rather unusual; yet his familial, socio-religious background created access to opportunity in knowledge and social circle (Steenbrink, 1994; Hadler, 1998; Rusydi, 2001; Hamka, 1982a; Hamka 1982b). He was born in Minangkabau, Sumatra into a family known for its religious authority; his father Hadji Rasul was a well-known scholar in Sumatra (Abdullah, 2009). Hamka learned the traditional Islamic knowledge and Arabic at primary level and traveled extensively both within and outside Indonesia for knowledge. He spent some years studying in Mecca, a common practice among Southeast Asian Muslims at that time. He was inspired by the Egyptians 'Abduh's and Rị̣ā's reform ideas and eventually joined and led the Indonesian reformist organization of Muhammadiyah. Later in his life, he was appointed as the head of Muslim Council of Indonesia (Majlis Ulama Indonesia [MUI]). As a prolific author, Hamka wrote close to one hundred books, mostly in Indonesian but also a few books in Arabic; he penned on various subjects on Islam from mysticism (tașawwuf), women, theology to the romantic novel. His seminal work Tafsir al-Azhar was originally the morning lectures at a local mosque which later converted into a comprehensive tafsir .

Al-Sha'rāwī’s (1911-1998) scholarly background was quite usual (Darwish, 1998; Brinton, 2011; Osman, 2013). His scholarship on Islam started when he was young. He studied at an Islamic school where he learned the Islamic tradition knowledge. He memorized the Qur'an at the age of seven, and obtained a degree in teaching from al-Azhar University in 1943. He was a Professor at the Umm al-Qurā University, Saudi Arabia for ten years. He was also the Minister of Endowment (awqāf), an equivalent to Minister of Religious Affairs, in the late 70s. His shot to fame was due to his weekly religious program Nūr 'ala $N \bar{u} r$ on the Egyptian national television in the middle of the 70s (Osman, 2013). Al-Sha'rāwī could be considered as the pioneer of celebrity preachers that decades later became a social phenomenon in most parts of the Muslim world (http://www.sunnah.org/history/Scholars/sharawi.htm). His televised religious programs were watched by millions of Arabic speaking viewers. He wrote many books on various subjects of Islam from the Qur'an to women to theology (Hatem, 1998). His work Tafsìr al-Sha'rāwi was originally a compilation of his lectures delivered on television programs. They were later published by his students and family in the form of a book. 


\section{Twentieth Century Tafsīr: A Brief Overview}

As a literary genre, tafsir was only developed much later compared to other genres such as Hadìth (Saleh, 2015). The classical work is characterized by various multitudes of sectarian, political, jurisprudential persuasions, as much as the linguistic influence (Hidayatullah, 2014). Despite its vast corpus, the classical work received negative review from its critiques. Muhammad 'Abduh (Rị̣ā, 1973) claimed that classical and medieval works were very exclusive and comprehendible only to scholarly class. He argued that their excessive, lengthy often unnecessary jurisprudential (fiqh) and theological debates (kalam) have inadvertently distracting readers from the true message of the Qur'an. Modern tafsir works particularly in the twentieth century have shifted from that approaches, and most tafsir works are commonly identified in their less scholarly feature without compromising the characteristics of a tafsìr work.

The twentieth-century tafsir became more influential and significant due to socioeconomic changes that took place in the Muslim world. The establishment of printing houses helped to proliferate knowledge constructions among the people. It also created awareness among the people to learn more about Islam thus making the tafsir works as one of the sources of knowledge. Tafsir works then became the bridge between the scholarly group and the public; they were the public's means to the message of the Qur'ān. They demonstrate the dynamic relationship between the text and the reader by which it was mediated by the exegete's interpretation of the text. Here, the interests of the public particularly the literate lower middle class towards the message of the Qur'ān empowered the role of Muslims scholars and their authority (Zaman: 2002; Skovgaard-Petersen, 1997). At the turn of the early twentieth century, from Egypt to Turkey to India to Indonesia, many more vernacular tafsī $r$ were written.

\section{Shared Themes of the Twentieth-Century Exegeses: Hamka, Al-Sha'rawi and Verses Related to Women's Issues}

Many researches on Hamka's tafsir focused on his methodology in interpreting the Qur'an (Yusuf, 2005; Pink, 2010). Brinton's study (2011) focused on al-Sha'rawi as a preaching authority and his impact in the Middle East. However, little attention is paid to how the two works interpret verses related to women's issues that help to trace the common themes in the interpretation of the Qur'an of the twentieth century.

Women-related verses are the verses that inform socio-economic and political relations between gender with theological and legal implications. The verses prescribe the basis for human equality, matrimonial interactions that help to protect the spouses from personal biases and to preserve social order in the society. The tafsirs of Hamka and alSha'rāwī demonstrate that the contemporary discourse on women was considered not only as a sociological issue but also taken as moral-theological one that requires embracing ethicalmoral compass guided by the divine wisdom. The two scholars presented the notion of embracing God's social justice and order even if one finds certain texts not in agreement with his/her understanding of justice that is defined by the contemporary notion of human rights. Their works appeal for consciousness on Divine wisdom and the belief in superiority of His commandments that transcends beyond human's feeling and preference of certain social order. 


\section{Evoking Consciousness of Divine Wisdom through Gender Equality}

In verses related to human equality, both scholars use the verses to showcase that human dignity and equality are rooted from the divine sanction. Thus they do not fall within the discussions of human rights or philosophical ideas.

In his interpretation, Hamka argued for gender equality based on the notion of original human creation from a single entity (Qur'ān 4:1) that made them equal before God (Hamka, 1984b). Hamka viewed that humans are created out of an entity rather than from a male person to argue for gender equality. He also abandoned the notion of Eve's creation from Adam's left rib (Hamka, 1984) because he viewed that as only a Qur'ānic simile. Furthermore, he argued some men (mis)use the simile to construct women as less equal thus perpetuates female subjugation. Hamka showed examples from Islamic texts and history that women were as righteous as men. He constructed the notion of gender justice for his readers that both genders should have equal opportunity and help each other to promote social justice in their society (Hamka, 1984b, Hamka, 1984).

Al-Sha'rāwī interpreted Qur'ān 4:1 with Qur'ān 51:49 (that things are created in pairs) to indicate the inseparable nature of their creation. God created both man and woman of the same kind (jinsihi) man was created. Even though both are endowed with distinctive substance (Sha'rāwī, n.d.) the two kinds share the source of their original creation i.e. soil/earth that forms the basis for equality in their creation, thus negating the superiority of man over a woman (Sha'rāwī, 1982). Al-Sha'rāwī continued that the verse begins with "fear God one that created you..." hence is an indication that there should not be any negotiation on the equality of mankind (Sha' rāwi, 1994$)$. He compared Islamic points of view on women with unnamed pre-Islamic practices and ideologies: women innate nature is suitable with menial service; created out of impurity (najs); woman is created out of satanic acts and the evil-god but man is created out of the good-god (Sha'rāwī, 1982). He argues Islam has given women their rights/equality much earlier than the women in the West had; it guarantees their rights to consent in marriage, choosing the spouse, and to relinquish marriage (Sha'rāwī, 1990). God had put the measurement for their equality by granting them equal dignity and honor as humans (karäma al-insāniyya) who deserve equal rewards (for their virtuous actions). Brinton (2011) argued that "for Sha'rawi, religious truth always took precedence, which meant that contingencies were always modified and weighed against his understanding of the Qur'an and Hadīth before they were accepted" (Brinton, 2011)

Both scholars constructed the notion of gender justice and equality based on the Islamic framework. They evoke ethical-moral consciousness of their readers to embrace God's wisdom embedded in the Qur'ānic texts. Accepting God's wisdom is an ethicaltheological matter; it dictates social order and justice that surpasses one's personal preference and narratives.

\section{Modest Clothing and Identity Marker}

Modesty is considered not only as a profound character to embrace but also one that helps to maintain social order through respectful interaction between gender. It is understood that modesty is not only expressed internally like how one behaves and talks, but it is also connected to the physical appearance such as modest dressing.

Hamka emphasized modesty both in its form and substance. His argument for modesty for both men and women is based on two verses: Qur'ān 24:30 and Qur'ān 9:71 that remind them to lower their gaze and guard their modesty by hiding ornaments except for 
what is apparent, and to draw a veil over their bosoms. Hamka argued that the form of modesty may embrace an indigenous culture that allows a greater local adaptation and interpretation of modest clothing. The only principle of modest clothing is covering the 'awrah (intimate parts of a body to be concealed) as means to achieve modesty i.e. one's conscious submission to God's will (Hamka, 1984; Hamka, 1984).

Al-Sha'rāwī's interpretation on modesty focused more attention on the hijāb. Hijāb is supposed to protect the whole society from fitna (Safitri, 2010; Abou Fadl, 2001), to provide security and peace for the women, men and the family. He argued hijāb is a way to modesty and God's prohibition for a woman to reveal adornment to male strangers is to protect her from fitna (Sha'rāwī: 1990). Thus modesty is constructed as an antithesis to fitna, a seemingly woman inherent quality. Unveiling women's adornment to strangers amounts to immodesty, a source of marital problems. "By putting hijāb, men will not be able to compare his wife against the (beauty) of other women, thus creating a system of women protecting other women" (Sha'rāwī: 1990; Hoffman-Lad, 1987). Nevertheless, al-Sha'rāwī believed in spiritual benefit of hijāa as a means to instill deep religious training "tarbiyyah ìmāniyyah "amiqah" for women, and as the most effective protection against the arrow of villain and evil Satan "Siham al-shayțān al-marīqah al-țaishah". By prescribing a woman as fitna, unless she follows modesty rule in the form of physical appearance, i.e. wearing a hijāb, alSha'rāwī had inadvertently created the identity of a Muslim woman in contemporary Egypt. She must conform to this physical identification to belong to the modest personality.

The two scholars pointed to the issue of modesty not only as a sign of embracing modesty but also submitting to one's moral conscientious. Being modest is then considered pertinent to one's consciousness of God and one's identity as a Muslim. The identity of a Muslim woman was visibly emphasized and constructed that is largely drawn from the Islamic tradition and ideals.

\section{Polygamy and Social Criticism}

Polygamy has always been a contentious issue in the Muslim society. Its critiques believe that its permissibility is being abused and misused at the expense of justice to women and children. Malaysia for instance, has regulated the practice of polygamy as an effort to serve justice to women and children while Turkey and Tunisia have it banned in 1926 and 1956 respectively.

Hamka's interpretation on polygamy was based on two verses; Qur'ān 4:3 and 4:129 where he alluded his concern on the issue confronting his society. He read the verses within the social context of serving justice to female orphans. The permissibility of polygamy is understood within the contexts of avoiding injustice to the female orphans (through wealth exploitation), and the duty of being just to the co-wives in polygamous marriage (Hamka, 1984; Hamka, 1984). He was critical towards men who abused its permissibility yet failed to be fair to the co-wives. Hamka believed that being equal to the co-wives is hard to attain; unequal affection towards the co-wives however is a natural inclination thus is not included in the concept of being just. He was concerned about the practice of polygamy where justice to women and children is neglected. The abuse of polygamy became prevalent when it was easy to contract polygamous marriage. The family saw that being co-wives to a religious person was an honor (Hamka, 1984d; Hadler, 1998). Hamka gave the impression to his readers that, remaining in a monogamous marriage is the best alternative for men who value quality peaceful life (Hamka, 1984; Hamka, 1984c). 
Al-Sha'rāwī believed that polygamy is among the most controversial issue 'yuthìru jadalan kathīran' especially among the non-Muslims (Sha'rāwī, 1990). He viewed that in Qur'ān 4:3, being just to either an orphan wife by not exploiting her wealth, or in polygamous marriage is the essential message of the verse (Sha'rāwī: 1997; Sha'rāwī: 2000), but justice to wife is easy to execute if one maintains a monogamous marriage. By pointing to the existing (Egyptian) Family Law, al-Sha'rāwi pointed that the malpractice of polygamy has caused a real issue to the society where "irresponsible fathers prefer children from a wife over the others on clothing, shelter and learning" (Sha'rāwī, n.d). He offered his critical assessment on what he called 'hysteria' surrounding injustice polygamous practice in his society where Muslims now distrust the ruling prescribed by God; women hate polygamy even if it is a just one. He added "... being just (to co-wives) is not an option for men; it is not a moral choice that he can neglect, therefore this verse is a good reminder from God to men about it" (Sha "rāwī, n.d). Men must be just in giving his co-wives the shelter, family time and even the furniture. However, emotional attachment to one wife is beyond the control of a man thus he is not required to be just in this matter. Al-Sha'rāwi believed that the inability for man to be just even if he tries, as mentioned in Qur'ān 4:129 is on matter of emotional attachment or preference among the co-wives (Sha'rāwīi, 2003).

As an exegete, al-Sha' rāwī had to explain the rationale of polygamy where it should solve many social issues such as of unmarried women. He argued that God gives permissibility on polygamy because there are exceeding numbers of women "and there is no polygamy if there is no extra number of women" (Sha'rāwī,1990; Sha'rāwī, n.d.). His problem solving on polygamy is quite unconventional for he believed that unmarried women should accept polygamy because staying unmarried would give a woman an access to immoral acts (Sha'rāwī, 1982; Sha'rāwī, n.d.[b]). Polygamy is not against the nature of human beings 'lā yukhālif țabì'a al-nās' because God knows about their need. Al-Sha'rāwī does not agree polygamy to be banned because some situations warrant it such as in sickness. He argued, without specific evidence, that there are non-Muslim societies that solve their social problems with polygamy (Sha' $r a \bar{w} \bar{i}$, n.d.[b]).

The exegetes offered their social criticism towards the malpractice of polygamy in their societies. They corrected the notion and the practice of polygamy that focus on its permissibility rather than the associated concept of justice. The prevalent abuse of polygamy had caused a lot of stress to family institution in their societies. As social critiques that deeply rooted within the Islamic tradition, none of them called for its abolition, but reiterated that men must serve the ethics of polygamy i.e. justice. They provided the solution for this social issue based on the Islamic ideals thus understood as being the best approach to social problems in Muslim society. The criticism that they made on malpractices of polygamous marriage in their society was aimed at reconstructing its notion for a better family and social order. The criticism requires internal ethico-moral consciousness and reinterpreting the texts within the framework of Islam with its highest objective is to serve justice to all parties involved particularly women and children.

\section{Conclusion}

The interpretation of the Qur'ān in the twentieth century represented by the works of Hamka and al-Sha'rāwī has indicated that there are some common themes that they share. Studying these tafsir works enable us to uncover the embedded constructions of Islamic 
spirituality, Muslim identity, the centrality of the divine texts, and also the roles of 'ulamā in the modern lives of Muslims in Indonesia and Egypt.

One of the common themes of the twentieth century exegetical works is protecting and preserving a Muslim identity as Muslim societies were confronted with various modern philosophies and political ideologies such as nationalism, socialism, and communism. In extension, women issues were among the most contentious and debated issues in the Muslim world in the twentieth century. Muslim exegetes had to show Muslims that the Qur'an has to be their main reference for all issues that they face including the women issues. For example, hijāb has become the identity marker for the social activists in Islamic movements in Egypt (Ahmed, 2011). The exegetes constructed the female Muslim identity by quoting relevant Islamic texts, examples and conclusions from the lives of the Muslims in early Islamic history as well as the opinions of renowned Muslim scholars. In addition, comparison with the non-Islamic references was made to show the superiority of the Muslim lifestyles, thus conforming to these values is detrimental to one's Islamic identity. As people have many identity markers such as ethnicity and linguistics, religion also can be an identity marker (Schotmann and Camilleri, 2013). Anthropologist Abu-Lughod (2013) confirms in her study about the Egyptian women across professional careers, that identity as Muslims is crucial in promoting the sense of belongings within the Muslim community. Thus these exegetes have used their interpretations on verses related to women to construct a Muslim religious identity that alluded to the best behaviors of women (and of men).

The study on the twentieth-century tafsìr works indicates a strong Muslim cultural connection with their tradition and heritage. There was a paramount consciousness among the lay Muslims to learn about Islam, its sacred texts and rich history. Furthermore, Muslims now could have access to books and writings as means to gain knowledge, certainly not limited only to classrooms and halaqa (study circle) at the mosques. Easy availability of printings made knowledge construction and transmission, even from one continent to another, possibly easier than the previous centuries. Also, the exegetes played roles in instilling consciousness in the Muslim minds about the compulsory of learning their tradition. Eickelman and Piscatori (1996) called this as 'objectification of Muslim consciousness' in which Muslims in a large number questioned "about the identity and religion..., a question that places the role of Islam in one's ultimate permanent life in the hereafter". Even though Eickelman and Piscatori argued that the question of 'what it meant to be a Muslim' was popular during the global Islamic resurgence in the 70's, I would want to push this similar awareness among the Muslims to decades earlier. Back then, Muslims too, presumably not in massive scale like during the Islamic resurgence period, were aware of such question due to the roles of scholars who used mosques and classrooms to create that awareness. The political and social debates that took place in the Muslim world in the first half of the twentieth century awakened the Muslims with the spiritual-theological questions. 'Ulamā' and exegetes called for the return to the authentic teachings of Islam by giving lectures and writings; cited the sacred texts, and fundamental sources of Islam. Literate Muslims, regardless of their religious background, now could have more access to works that provided answers for their ethico-moral questions.

The interpretation of Hamka and al-Sha'rāwī on verses related to women's issues shows the cultural-intellectual continuity between the present and the past scholars. The deep appreciation of the past and its importance to the present is embraced by these two scholars. They formed relationship with the previous tradition by way of adhering to hermeneutical principles employed by the previous scholars of the tafsir tradition. Walid Saleh (2015) 
explained this cultural-intellectual connection between any exegete with the corpus of tafsir tradition is due to the fact that tafsir is a 'genealogical tradition'. The connection is done through the process in which any exegete would benefit from this vast tradition through personal judgement and synthesis. Even if the exegete disagrees with some elements in the tradition, the expression of disagreement is permissible but he is not allowed to completely disconnect from it. Saleh gave an example of disagreement some scholars have with the use of isrāiliyyāt in tafsīr tradition, but who have no authority to completely remove them from the tradition. He viewed that "the tradition (of tafsir ) was always conceived as a whole, and as such an exegete could and did go back to highlight a now-forgotten method, position, or interpretation. As such, the interpretive tradition had the eerie ability to manifest itself in its totality even at the moment an exegete thought he succeeded in changing it." (Saleh, 2004; Saleh 2015). Both Hamka and al-Sha'rāwī remained true to the exegetical principles; they might have disagreed with some of the scholars within the tradition, but theirs is just like one of the many disagreement expressed towards the vast tafsīr tradition. Their opinions on the tradition however, would remain important to the enrichment of the tafsïr's corpus that continues to be appreciated by the coming generations of exegetes.

\section{References}

Abdullah, Taufik. 2009. Schools and Politics: The Kaum Muda Movement in West Sumatra (1927-1933). Singapore: Equinox Publishing.

Abou el-Fadl, Khaled. 2001. Speaking in God's Name: Islamic Law, Authority and Women. Oxford: Oneworld.

Abu-Lughod, Lila. 2013. Do Muslim Women Need Saving?, Harvard: Harvard University Press.

Ahmed, Leila. 2011. A Quiet Revolution: The Veil's Resurgence, from the Middle East to America, Yale: Yale University Press.

Darwish, Adel. 1998. "Obituary: Sheikh Mohamed Mutwali Sha'rāwī”, retrieved from http://www.independent.co.uk/arts-entertainment/obituary-sheikh-mohamedmutwali-sharawi-1165880.html.

Eickelman, Dale F and Piscatori, James. 1996. Muslim Politics, Princeton: Princeton University Press.

Hadler, Jeffrey, 1998. "Home, Fatherhood, Succession: Three Generations of Amrullahs in Twentieth-Century Indonesia". Indonesia, 65:123-154

Hamka. 1982a. Ayahku: Riwayat Hidup H. Abdul Karim Amrullah dan Perjuangan Kaum Agama di Sumatera, Jakarta: Umminda

Hamka, 1982b. Kenang-Kenangan Hidup, Kuala Lumpur: Pustaka Antara.

Hamka, 1984a. Tafsir Al-Azhar, Jakarta: Pustaka Panjimas

Hamka, 1984b. Kedudukan Perempuan Dalam Islam, Jakarta: Pustaka Panjimas.

Hamka, 1984c. Soal Jawab Agama Islam, Kuala Lumpur: Pustaka Melayu Baru.

Hatem, Mervat F. 1998. "Secularist and Islamist Discourse on Modernity in Egypt and the Evolution of Post-Colonial Nation-State" in Islam Gender and Social Change (eds.) John L Esposito and Yvonne Yazbeck Haddad. Oxford: Oxford University Press.

Hidayatullah, Aysha A. 2014. Feminist Edges of the Qur'an. Oxford: Oxford University Press.

Hoffman-Ladd, Valerie J. 1987. "Polemics on the Modesty and Segregation of Women in Contemporary Egypt”. International Journal of Middle East Studies, 19/1: 23-50. 
http://www.sunnah.org/history/Scholars/sharawi.htm

Brinton, Jacquelene, 2011. "Preaching And The Epistemological Enforcement Of Ulama Authority: The Sermons of Muhammad Mitwalli Sha'rāwī”, Intellectual Discourse, 19, 97-121.

Osman, Tarek. 2013. Egypt on the Brink: From Nasser to Muslim Brotherhood. New Haven: Yale University Press.

Pink, Johanna. 2010. "Tradition, Authority and Innovation in Contemporary Sunni Tafsīr. Towards a Typology of Qur'anic commentaries from the Arab World, Indonesia and Turkey". Journal of Qur'anic Studies, 12:56-82.

Riḍā, Rashīd, 1973. Tafsīr al-Qur'ān al-Hakìm : al-Shahīr bi-Tafsìr al-Manār, Beirut : Dār al-Ma'rifah lil-Ṭibā'ah wa-al-Nashr.

Rusydi, Hamka, 2001. "Kenangan Peribadi Tentang Ayahku Hamka", in Pemikiran dan Perjuangan Hamka, ed. Md Sidin Ahmad Ishak, Kuala Lumpur: ABIM

Safitri, Dian Maya. 2010. "What Went Wrong with the Veil? A Comparative Analysis of the Discourse of the Veil in France, Iran, and Indonesia". Al-Jami'ah, 48/1:82-100.

Saleh, Walid A. 2004. The Formation of the Classical Tafsìr Tradition: The Qur'an Commentary of al-Tha'labi (D. 427/1035).

Saleh, Walid A. 2015. "Qur'anic Commentaries", The Study Qur'an (eds.) Seyyed Hossein Nasr et al., New York: HarperOne.

Schotmann, Sven, Camilleri, Joseph. 2013. "Culture, Religion and the Southeast Asian State", in Culture, Religion and Conflict in Muslim Southeast Asia: Negotiating Tense Pluralisms (eds.) Joseph Camilleri and Sven Schottmann. London: Routlege.

Sha' rāwī, Muḥammad Mutawallī. (n.d). Tafsīr al-Sha 'rāwī, Cairo: Akhbar al-Yawm.

Sha'rāwī, n.d.(b). Al-Shaykh al-Sha 'rāwī wa al-Mar'ah al-Muslima. n.p.: Dar al-Sahwah li al-Nashr

Sha 'rāwī. 1982. Kayfa Nafham al-Islām. Cairo: Maktaba al-Qur'an.

Sha'rāwī. 1990. Al-Mar'ah fi al-Qur'an al-Karim. Cairo: Akhbar al-Yawm.

Skovgaard-Petersen, Jakob, 1997. Defining Islam for the Egyptian State: Muftis and Fatwas of Dār al-Iftā'. Leiden: Brill.

Steenbrink, Karen, 1994. "Hamka (1908-1981) and the Integration of the 1slamic Ummah of Indonesia", Studia Islamika, 1:3:119-147

Yusuf, Milhan, 2005. "Hamka's Method in interpreting legal verses of the Qur'an". Approaches to the Qur'an in Contemporary Indonesia (ed.) Abdullah Saeed. Oxford: Oxford University Press.

Zaman, Muhammad Qasim, 2002. The Ulama in Contemporary Islam: Custodians of Change. Princeton: Princeton University Press. 